\title{
TAFSIR SOSIAL KONTEKSTUAL IBADAH KURBAN DALAM ISLAM
}

\author{
Oleh: \\ Choirul Mahfud \\ Institut Teknologi Sepuluh Nopember (ITS) dan Lembaga Kajian Agama dan Sosial (LKAS) \\ Surabaya \\ Email: choirul_mahfud@yahoo.com
}

\begin{abstract}
Abstrak: Dalam studi Islam, kurban merupakan salah satu ajaran mulia. Kurban secara bahasa dimaknai mendekatkan diri. Secara istilah, kurban diartikan segala upaya mendekatkan diri kepada Allah dengan cara menjalankan apa saja yang diperintahkan sekaligus menjauhi yang dilarang. Ibadah kurban termasuk ajaran ideal. Namun begitu, dalam praktiknya masih ada persoalan yang dijumpai kenapa ada orang yang belum mengamalkan ajaran ibadah kurban secara maksimal dalam kehidupannya. Hal itu disinyalir, diantaranya, karena adanya pemahaman yang cenderung tekstual ketimbang kontekstual sosial sepanjang hayatnya. Oleh karena itu, tulisan ini lebih memfokuskan pada pembahasan apa yang dimaksud ibadah kurban dalam Islam? Bagaimana tafsir sosial ibadah kurban dalam Islam tersebut? Apa saja manfaat menjalankan ibadah kurban? Lalu, bagaimana implementasi dan implikasi kurban dalam Islam bagi kehidupan setiap manusia di dunia dan akhirat.
\end{abstract}

Kata Kunci: Kurban, Tafsir Sosial Kontekstual, Islam

\section{Pendahuluan}

Kurban merupakan ajaran yang hampir menyatu dalam segi waktu pelaksanaannya dengan ibadah haji. Namun berbeda dari segi tempat dan pelakunya. Ibadah kurban biasa dilakukan pada saat hari raya idul adha. Dengan lain bahasa, bila kita mendengar Idul Adha, maka langsung terlintas pada benak kita akan tradisi ber-qurban, yang sangat identik dengan menyembelih hewan qurban.

Dalam konteks ini, Komaruddin Hidayat dalam buku "Memahami bahasa Agama" mengurai benang kusut pemahaman bahasa agama yang perlu dimengerti untuk mencari esensi dalam praktik kehidupan beragama sehari-hari (Komaruddin Hidayat, 1996: 8-38).

Fuad Amsari dalam buku "Islam Kaafah: Tantangan Sosial dan Aplikasinya di Indonesia”, mengulas pentingnya upaya menjadi muslim yang sempurna dan total dalam mempraktikkan ajarannya (Fuad Amsari, 1995: 19-89). Dalam hal ini, tentu diantaranya adalah soal bagaimana mengamalkan ajaran kurban sesuai dengan syariat dan tuntunan agama Islam. 
Namun tidak berlebihan, bila kita mau terus menerus kembali berusaha menjawab jujur, bahwa peringatan hari-hari besar keagamaan atau aktivitas dan praktik ibadah seperti kurban apakah lebih kita jadikan sebagai kegiatan rutin biasa (ritual) atau memang sebagai ekspresi iman dan taqwa karena Allah.

Perilaku kita tetap berjalan seperti hari-hari biasanya atau berubah setelah menjalankan semua ibadah. Kita tidak peduli terhadap sesama, kita tidak takut kepada peringatan-Nya atau sebaliknya. Lalu tindakan yang merugikan orang banyak tetap saja kita lakukan atau tidak. Pola hidup yang jor-joran juga semakin surut atau diganti dengan pola hidup suka berbagi.

Realitas kehidupan yang menunjukkan banyak saudara-saudara di sekitar kita yang hidup dalam kemiskinan, serba kekurangan dan mengalami tekanan hidup yang semakin berat tentu bagian dari tantangan ibadah yang lebih praktis dan berdampak secara sosial. Dalam konteks inilah, pembahasan dan penafsiran sosial dalam praktik ibadah kurban penting didiskusikan lebih lanjut.

Lebih dari itu, di setiap saat perayaan hari raya keagamaan tiba, kita juga selalu diingatkan mengenai pesan moral yang terkandung di dalamnya. Kita diingatkan untuk selalu mengagungkan nama-Nya, membagi kasih sayang terhadap sesama, dan kita diingatkan untuk selalu menjauhi larangan-Nya. Apakah kita kemudian dengan sadar melaksanakan semua itu? Apakah kita peduli dengan apa yang diperintahkan-Nya dan menjauhi apa yang dilarang-Nya?

\section{Pembahasan}

Dari dulu hingga sekarang, topik kurban selalu menjadi bahasan penting dan menarik. Di awal tulisan ini, pembahasan difokuskan pada apa yang dimaksud dengan kurban. Secara etimologi, qurban yang sering ditulis dalam tulisan ini dengan huruf awal $\mathrm{k}$ berarti mendekat/pendekatan. Sedangkan menurut istilah adalah usaha pendekatan diri seorang hamba kepada penciptanya dengan jalan menyembelih binatang yang halal dan dilaksanakan sesuai dengan tuntunan, dalam rangka mencari ridla-Nya. Salah satu ajaran Islam yang penuh dengan kesakralan (suci) dan juga syarat dengan muatan kemanusiaan adalah ibadah qurban.

Dalam konteks ini, ibadah kurban adalah kesempatan bagi si miskin untuk merasakan kenikmatan dari si kaya. Mengalirnya darah-darah suci dari hewan qurban akan menghanyutkan 
noktah-noktah hitam di hati manusia, memercikkan aroma harum jalinan kasih antara sesama sembari menyemaikan rona ceria di wajah masing-masing.

Lewat ibadah kurban, akan tumbuh rasa kepedulian sosial terhadap sesama. Terlebih saat ini bangsa Indonesia sedang berduka, di mana saudara-saudara kita yang tertimpa musibah bencana alam yang telah merenggut ratusan ribu nyawa, keluarga dan harta. Melalui ibadah kurban ini, kita ketuk pintu hati kemanusiaan, rasa kepedulian sosial serta merasa senasib sepenanggungan terhadap apa yang menimpa saudara-saudara kita di negeri tersebut.

Dari sinilah, M. Quraish Shihab menyatakan ibadah kurban merupakan ibadah yang sempurna sepanjang hayat manusia. Pasalnya, ibadah kurban merupakan ajaran tertua sepanjang sejarah kehidupan manusia yang terus berlangsung hingga saat ini (M. Quraish Shihab, 2008: 3840).

\section{Tafsir Sosial Kontekstual Ibadah Kurban}

Memahami ibadah kurban perlu banyak pendekatan, salah satunya adalah pendekatan sosial kontekstual. Ahmad Izzan dalam buku “Ulumul Qur'an: Telaah Tekstualitas dan Kontekstualitas Al-Qur'an” menjelaskan bahwa memahami dan menafsirkan al-Qur'an bisa dilakukan dengan cara mengaitkan antara teks al-Qur'an dengan konteksnya untuk kesempurnaan pemahaman (Ahmad Izzan, 2011: 8-19).

Dengan nada yang berbeda tapi sama maksudnya, Syafrudin dalam buku "Paradigma Tafsir Tekstual \& Kontekstual”, juga mengungkap kelebihan pendekatan kontekstual ketimbang hanya dengan memakai paradigma tekstual (Syafrudin, 2009: 19-29). Menurutnya, pendekatan kontekstual bisa menjembatani pemahaman teks yang kadang terputus dan terhenti pada bacaan dan tulisan. Di sini, pendekatan konteks dianggap bisa mengarahkan pembaca pada tujuan dan tindakan nyata.

Pradana Boy dalam buku "Fikih Jalan Tengah: Dialektika Hukum Islam dan Masalahmasalah Masyarakat Modern” menengarai bahwa problem krusial penafsiran al-Qur'an memang selalu berujung pada ranah fikih sebagai kunci praktis dalam ajaran Islam. Di sinilah, ungkap Boy, perlunya jalan tengah yang lebih arif, bijak, adil dan fleksibel sebagai respons keunikan tradisi, budaya dan khazanah Islam yang tersebar di segala penjuru alam dan zaman (Pradana Boy, 2008: 4-14). 
Secara epistemologis, Abdul Mustaqim dan Sahiron Syamsudin (ed.) dalam buku "Epistemologi Tafsir Kontemporer", memberikan dasar-dasar pengetahuan tentang tafsir kontemporer yang sesuai dengan konteks tetapi tetap tidak melupakan teks aslinya (Abdul Mustaqim dan Sahiron Syamsudin (ed.), 2011: 23-48).

Namun dalam konteks ini kita diingatkan oleh Islah Gusmian dalam buku "Khazanah Tafsir Indonesia, dari Hermeneutika hingga Ideologi”, terkait tafsir menafsir kita perlu memahami dan menghayati apakah penafsiran yang dimaksud mengarah pada kepentingan tertentu dan ideologi-ideologi ataukah murni pada penafsiran yang membawa ke arah keadilan dan kesejahteraan sosial (Islah Gusmian, 2003: 8-29).

Hal itu semua merupakan cakrawala dan wawasan baru yang menarik untuk dijadikan referensi pemahaman dalam studi tafsir sosial kontekstual dalam suatu masalah dan bahasan keislaman. Nashruddin Baidan dalam buku “Wawasan Baru Ilmu Tafsir”, mengungkap pentingnya penafsir dan pembaca untuk memupuk wawasan baru dalam semua bidang keilmuan, tidak terkecuali dalam ilmu tafsir itu sendiri (Nashruddin Baidan, 2011: 5-18).

Dari sini, memahami ibadah kurban bukan semata-mata ibadah individual. Ibadah kurban sebagai ibadah yang secara khusus dilaksanakan sekali dalam setahun dalam hitungan bulan Qamariyah, tepatnya pada hari besar Islam yaitu Idul Adha, merupakan ibadah sosial yang luarbiasa manfaatnya. Ibadah kurban termasuk hari raya besar dalam agama Islam. Penyebutan hari besar Islam untuk idul adha ini disebabkan beberapa hal. Pertama, pada hari itu kaum muslim melakukan shalat sunat Idul Adha. Kedua, adanya perhelatan agung yaitu ibadah haji di Makkah. Ketiga, dalam momentum ini pula, ada peristiwa penyembelihan hewan kurban.

Pada masa Rasulullah, konon katanya, peringatan hari raya Idul Adha sangat semarak melebihi semaraknya hari raya Idul Fitri. Namun, hal itu berbeda dengan sekarang, justru sebaliknya Hari Raya Idul Fitri jauh lebih semarak dibanding Idul Adha. Memang banyak faktor yang melatari kenapa saat ini berbeda dengan kehidupan di masa rasulullah. Terlepas dari perdebatan atas persoalan ini, fenomena kurban menjadi penting untuk dicari hikmahnya (M. Quraish Shihab, 1997: 46).

Dalam momen kurban, hampir setiap muslim yang berkemampuan melaksanakan penyembelihan hewan kurban, entah secara perorangan ataupun berkelompok. Di sekolahsekolah pun diadakan penyembelihan hewan qurban sebagai suatu sarana untuk mendidik siswa. Secara etimologis, qurban diartikan mendekat/ pendekatan. Dalam pengertian terminologisnya 
qurban adalah usaha pendekatan diri seorang hamba kepada penciptanya dengan jalan menyembelih binatang yang halal dan dilaksanakan dengan tuntunan, dalam rangka mencari ridla-Nya (QS Al Maidah, 5: 27).

Bila dilacak historisitasnya, ibadah qurban sudah ada sejak Nabi Adam. Menurut M. Quraish Shihab, dalam tafsir al-Misbah, qurban pertama kali yang terjadi di muka bumi ini adalah qurban yang diselenggarakan oleh dua putera Nabi Adam (Habil dan Qabil) kepada Allah (M. Quraish Shihab, 2002: 30). Secara formalistik, ungkap Quraish Shihab, sejarah ibadah qurban bermula dari Nabi Ibrhaim As. Yakni, tatkala ia bermimpi disuruh Tuhan-nya untuk menyembelih Nabi Ismail As, seorang putra yang sangat dicintainya (Q.S Ash-Shaffat, 37: 102110). Singkat alkisah, dari persitiwa kenabian Ibrahim inilah ibadah qurban muncul dan menjadi tradisi umat Islam hingga saat ini. Apa makna sosial ibadah qurban?

Sebetulnya, banyak makna yang dapat dipetik dari ibadah qurban ini, baik secara ruhiyah maupun secara sosial-kemasyarakatan. Secara ruhiyah, ibadah ini bisa menumbuhkan dan meningkatkan kesadaran ritual dari para pelakunya. Secara sosial-kemasyarakatan, ibadah qurban akan bermakna apabila kerelaan dan keikhlasan orang-orang yang melaksanakan qurban berimbas pada perilaku keseharian dan perhatiannya pada sesama, utamanya kaum miskin dan mustadzafiin.

Secara esensial, tentu saja, tujuan ibadah qurban bagi umat Islam adalah semata-mata mencari ridla Allah SWT. Ibadah qurban ini dimaksudkan untuk memperkuat dan mempertebal ketaqwaan kepada Allah. Allah akan menilai ibadah ini sebagai wujud ketaqwaan hamba kepada-Nya. Hal ini dijelaskan oleh Allah dalam firman-Nya: "Daging-daging unta dan darahnya itu sekali-kali tidak dapat mencapai (keridhaan) Allah, tetapi ketakwaan dari kamulah yang dapat mencapainya." (QS Al Hajj, 22: 37). Hal ini pulalah yang menjadi sebab tertolaknya qurban salah seorang dari kedua putera Nabi Adam A.S dan diterima-Nya qurban yang lain. Bukanlah suatu nilai yang tinggi dan banyak di mata Allah, qurban yang banyak tetapi tanpa keikhlasan dan ketakwaan orang yang berqurban hal itu sama saja tak ternilai di mata Allah SWT. Kebanyakan kita menilai ibadah qurban, mungkin cenderung melihat sesuatu dari lahirnya yang tampak, padahal Tuhan melihat sebaliknya yaitu keikhlasan.

Mungkin tatkala kita melihat seseorang berqurban hanya dengan seekor kambing, kita menganggapnya remeh. Kita lebih memandang besar dan hormat kepada orang yang berqurban dengan seekor sapi yang gemuk. Padahal belum tentu penilaian kita benar. Sebenar-benar penilai 
hanyalah Allah. Mungkin saja di mata Allah lebih tinggi nilai seekor kambing tadi karena taqwa di hati orang yang berqurban. Jadi tak ada yang menghalangi seseorang untuk berqurban sedikit jika disertai hati yang suci, taqwa dan ikhlas. Dan tidak ada kepastian diterimanya qurban yang banyak dari seseorang tanpa ketaqwaan dan keikhlasan. Namun di sini bukan berarti tidak diperbolehkan berqurban dengan jumlah banyak, saya kira, berqurban banyak pun boleh asal disertai dengan taqwa dan ikhlas. Taqwa dan ikhlas menjadi inti amal, mengapa? Sebab, banyak sebagian dari kita tatkala beramal hanya untuk mencari muka, dan pujian semata.

Selain makna sosial di atas, Ibadah qurban juga bisa menjadi sarana untuk membentuk kepribadian yang penuh toleransi, media menebar kasih sayang, serasi dan jauh dari keegoisan. Hubungan yang baik akan terjalin antara yang kaya dan miskin. Setidaknya selama beberapa hari tersebut orang-orang yang miskin akan merasakan kesenangan. Kalau saja hal itu bisa berlangsung terus-setidaknya untuk kebutuhan pokok-tentu tingkat kemiskinan di masyarakat kita akan menurun. Di dalam masyarakat akan tercipta ketenangan dan ketentraman. Sebab, tidak ada lagi perbedaan status/ keadaan hidup yang mencolok. Pengorbanan yang tumbuh dalam pelaksanaan ibadah qurban itu akan mengikis sikap egois dan kikir. Berkurangnya-atau bahkan hilangnya-sikap egois dan kikir itu akan berpengaruh baik bagi kehidupan dan penghidupan orang itu sendiri dan masyarakat luas.

Selanjutnya, berqurban merupakan ibadah wajib menurut sebagian ulama dan sunnat muakkad menurut ulama yang lain, dengan berqurban pula kita mendidik diri kita dan keluarga untuk meresapi makna pengorbanan sebagaimana Nabiyullah Ibrahim As memberikan contoh pengorbanan secara hakiki, dan penyembelihan hewan qurban adalah salah satu ritual dari makna pengorbanan itu untuk menggapai ketaqwaan kepada Allah SWT. Sehingga banyaknya hewan qurban yang disembelih menunjukkan respon masyarakat terhadap seruan ibadah qurban makin meningkat. Daging Qurban, bukan semata pesta sate dan gulai? Tetapi, Ibadah qurban yang kita tunaikan sudah saatnya berfungsi bukan saja menggugurkan kewajiban tapi lebih dari itu mampu memberikan manfaat dan menjadi solusi sebagai jawaban atas kondisi riil yang terjadi di masyarakat. Banyak dari kebiasaan kita dalam berqurban hanyalah identik dengan pesta sate dan gulai dalam 2 sampai 3 hari setelah Idul Adha, sementara dalam waktu 12 bulan ke depan kembali masyarakat (terutama di daerah-daerah miskin) memakan daging hanyalah menjadi khayalan, belum lagi kondisi alam Indonesia yang rentan terhadap bencana alam, yang selalu saja menjadi pemandangan umum ketika bencana alam tiba. 
Padahal, dibalik kesadaran kaum muslimin untuk berqurban serta melimpahnya hewan yang diqurbankan pada hari raya Idul Adha dan hari Tasyrik, tersimpan potensi yang sangat besar bahwa daging qurban digunakan sebagai sarana untuk membina masyarakat miskin, serta daerah-daerah bencana alam. Sebagian yang lain dicadangkan untuk mengantisipasi daerahdaerah yang rawan bencana alam.

Pelaksanaan qurban yang dilakukan oleh umat terdahulu memang sangat berbeda dengan syari'at qurban dalam Islam. Dalam Islam, risalah qurban merupakan ibadah yang syarat dengan makna. Kisah pengurbanan Nabi Ibrahim As. yang hendak mengurbankan anaknya, Ismail As yang kemudian diganti oleh Allah dengan domba, mengandung pesan bahwa pelaksanaan qurban selayaknya tidak membawa derita bagi manusia. Patut direnungkan bahwa, pelaksanaan ibadah qurban dalam Islam tidak hanya mengandung dimensi ibadah kepada Allah, tapi juga dimensi kemanusiaan. Dimensi kemanusiaan ini nampak pada distribusi daging hewan qurban kepada yang berhak (Q.S.al-Hajj, 22: 36). Karenanya, para ulama ada yang membagi daging qurban menjadi tiga, yaitu: dimakan, diberikan kepada fakir miskin, dan disimpan. Sebagaimana sabda Rasulullah SAW "Makanlah, simpanlah, dan bersedekahlah." Walaupun demikian, dimensidimensi tersebut tidak akan bermakna apa-apa bila tanpa dilandasi dengan refleksi taqwa kepada Allah SWT. Dengan kata lain, aplikasi solidaritas sosial yang diwujudkan melalui qurban harus dilandasi niat yang ikhlas. Bukan niat untuk mencari popularitas, ingin dikenal orang dermawan atau ingin dipikir orang hebat.

Lebih dari itu, pembagian daging qurban kepada mereka yang barhak merupakan upaya pendekatan psikologis atas kesenjangan sosial antara si miskin dan si kaya. Ibadah qurban adalah wahana hubungan kemanusiaan yang dilandasi oleh semangat sense of belonging dan sense of responsibility yang bisa menyuburkan kasih sayang antar sesama dalam rangka untuk mendekatkan diri kepada Allah., s.w.t, (taqarrub ilallah). Dengan adanya ibadah qurban, dimaksudkan pula untuk menjembatani hubungan antara si kaya dan si miskin agar tetap harmonis. Si kaya tidak menyombongkan dirinya dan si miskin pun merasa bahwa ia tidak sendiri memikul hidup yang berat ini. Ternyata, masih banyak saudaranya (para aghniya') yang senantiasa ikhlas memberikan bantuan kepada mereka yang lemah (para dhu'afa).

Wujud kepedulian sesama lewat ibadah qurban ini merupakan satu rangkaian pengabdian kepada Allah yang memiliki dimensi ibadah murni dan juga dimensi kemanusiaan. Dengan kata lain, hablun minannas merupakan salah satu faktor terjalinnya hablun minallah secara baik. 
Sesuai dengan asal katanya "Qaruba" yang berarti dekat. Dengan demikian ibadah qurban adalah mendekatkan diri kepada Allah sekaligus ungkapan syukur kepada-Nya atas nikmat yang diberikan kepada kita. Inilah yang dimaksudkan oleh Allah., s.w.t, dalam Q.S.al-Hajj, 22: 36.

Lewat ibadah qurban, akan tumbuh rasa kepedulian sosial terhadap sesama. Melalui ibadah qurban ini kita ketuk pintu hati kemanusiaan, rasa kepedulian sosial serta merasa senasib sepenanggungan terhadap apa yang menimpa saudara-saudara kita tersebut.

\section{Manfaat Ibadah Kurban}

Mau merasakan manfaat ibadah kurban? Jawabannya adalah cobalah, maka akan tahu manfaatnya langsung. Kalimat pernyataan dari pertanyaan tersebut bukan pertama kali saya tujukan untuk orang lain, tetapi saya tujukan terlebih dahulu untuk saya pribadi. Bagi saya, mengajak diri sendiri itu bagian awal yang penting. Hal ini juga bagian dari bentuk pelaksanaan ajaran hadits nabi Muhammad, yaitu: Ibda' bi Nafsi artinya mulailah dari diri sendiri.

Awalnya, memulai belajar berkurban memang cukup berat. Perasaan cinta harta hasil kerja keras membuat setiap manusia kadangkala berpikir ulang untuk mau melakukan pengurbanan. Hal ini wajar dan inilah ujian awal yang biasa dirasakan dan dialami oleh setiap manusia. Apalagi bagi sebagian dari kita yang berpenghasilan pas-pasan. Tentu kebanyakan orang semakin berpikir lebih dari biasanya. Oleh karena itu, niat awal untuk segera ikut serta dalam ibadah kurban menjadi penting. Niat baik adalah awal yang baik.

Perasaan senang untuk melakukan setiap ibadah, termasuk kurban, adalah bagian dari kebutuhan manusia dari hati nurani yang patut diperhatikan. Bila awalnya senang, akhirnya juga senang. Ada istilah dalam bahasa Arab "Man Jadda Wajada" atau dalam Bahasa Inggris "There is Will, There is Way”. Maksudnya barang siapa yang bersungguh-sungguh pasti ada jalan. Di sinilah, perasaan senang itu bisa diciptakan dan diupayakan bila kita mau.

Secara psikologi, Monty Satiadarma menyatakan bahwa perasaan senang dan suasana kebahagiaan seseorang ditentukan oleh kemampuan menerima keadaan, melihat situasi dari sudut pandang positif, menghayati makna pengalaman hidup, merelakan pengalamannya sebagai perubahan dalam hidup, dan bisa melepaskan diri dari belenggu pengalaman emosional.

Dalam hal ini, dapat dipahami bahwa upaya untuk membuat senang dalam melakukan setiap kebaikan dan ibadah ternyata ada banyak cara dan bisa melalui banyak media. Salah satu 
caranya adalah mencari tahu apa manfaat bagi kita dalam melakukan ibadah dan kebaikan tersebut. Mengkaji dan membahas manfaat ibadah kurban bisa membuat kita semakin tahu. Bila kita sudah tahu manfaatnya, biasanya kita mau melakukan segala bentuk pengurbanan dan amal kebaikan lainnya. Bahkan, kita seringkali semakin lebih bersemangat untuk berbuat kebaikan tersebut. Pertanyaannya, apa saja manfaat kurban bagi hidup kita di dunia dan akhirat nanti?

Sebelum menjawab pertanyaan di atas, di sini perlu dipahami bahwa kurban yang dimaksud di sini utamanya adalah ibadah kurban hewan pada hari raya Idhul Adha yang dilakukan oleh setiap orang muslim. Namun begitu, kurban di sini juga boleh dimaknai pada aktivitas-aktivitas lainnya yang memiliki unsur pengurbanan dan perbuatan kebaikan.

Bila kita mau dan ingin mengetahui sungguh-sungguh apa saja manfaat dari kurban yaitu Allah telah menjanjikan beberapa keutamaan bagi umat muslim yang menunaikan ibadah kurban, diantaranya: Pertama, dihapuskan dosa dan salahnya. Rasulullah., s.a.w, bersabda kepada anaknya, Fatimah, ketika beliau ingin menyembelih hewan qurban. "Fatimah, berdirilah dan saksikan hewan sembelihanmu itu. Sesungguhnya kamu diampuni pada saat awal tetesan darah itu dari dosa-dosa yang kamu lakukan. Dan bacalah: Sesungguhnya shalatku, sembelihanku, hidupku dan matiku hanya untuk Allah., s.w.t, Tuhan Alam Semesta.” (HR. Abu Daud dan At-Tirmizi).

Kedua, hewan kurbannya akan menjadi saksi amal ibadah di hari kiamat nanti. Dari Aisyah, Rasulullah., s.a.w, bersabda: "Tidak ada amalan anak cucu Adam pada hari raya qurban yang lebih dicintai Allah melebihi dari mengucurkan darah (menyembelih hewan qurban), sesungguhnya pada hari kiamat nanti hewan-hewan tersebut akan datang lengkap dengan tanduktanduknya, kuku-kukunya, dan bulu-bulunya. Sesungguhnya darahnya akan sampai kepada Allah (sebagai qurban) di manapun hewan itu disembelih sebelum darahnya sampai ke tanah, maka ikhlaskanlah menyembelihnya." (HR. Ibn Majah dan Tirmidzi). Ketiga, orang yang berkurban dicintai Allah. Bersumber dari hadist pada poin tersebut di atas, berkurban termasuk amalan yang dicintai Allah. Itu berarti bahwa setiap hamba yang melaksanakannya akan memperoleh kecintaan dari-Nya.

Keempat, orang berkurban dikuatkan keimanannya. Dengan berkurban, setiap mukmin dapat mengingat kembali bagaimana kecintaan Nabi Ibrahim dan kesabaran Nabi Ismail dalam memenuhi perintah Allah. Kisah ini dijadikan sebagai teladan bagi mereka untuk memperkuat imannya kepada Allah. 
Kelima, orang berkurban dibalas dengan kebaikan dan pahala yang berlimpah. Dari Zaid ibn Arqam, mereka berkata: "Wahai Rasulullah., s.a.w, apakah kurban itu?" Rasulullah menjawab: "Qurban adalah sunnahnya bapak kalian, Nabi Ibrahim.” Mereka menjawab: “Apa keutamaan yang kami akan peroleh dengan kurban itu?" Rasulullah menjawab: "Setiap satu helai rambutnya adalah satu kebaikan."Mereka menjawab: "Kalau bulu-bulunya?" Rasulullah menjawab: "Setiap satu helai bulunya juga satu kebaikan" (HR. Ahmad dan ibn Majah).

Sungguh luar biasa manfaatnya, bukan? Oleh karena itu, mari kita semakin bersemangat untuk memulai senang dan ikhlas berkurban karena Allah. Secara ritual, ibadah kurban biasanya kita lakukan sekali dalam setahun saat hari raya Idul Adha. Rasanya memang baru kemarin bila kita berkumpul merayakan Idhul Fitri sebagai hari kemenangan melawan hawa nafsu. Saat Idul Adha tiba, kita berkumpul kembali dalam rangka merayakan Idul Adha yang memiliki hikmah dan makna yang amat penting untuk ditangkap dalam perspektif ajaran agama Islam yang substansial. Idul Adha merupakan ritual keagamaan yang syarat makna dan nuansa simbolikmetaforis yang perlu ditafsiri secara kontekstual dalam pijakan nilai-nilai universalitas Islam.

Adakah pesan dan pelajaran penting yang dapat dipetik dalam perayaan ibadah kurban? Di setiap merayakan Idhul Adha, kita sesungguhnya diajak berpikir sejenak tapi mendalam maknanya. Utamanya dalam upaya untuk mengenang keteladanan Nabiullah Ibrahim a.s. dan Siti Hajar a.s. ketika ingin mendapatkan hingga melahirkan, mendidik dan mengasuh anak sholih. Putra Nabi Ibrahim yang pada bernama Ismail tersebut pada akhirnya juga menjadi salah satu nabi Allah., s.w.t. Keberhasilan beliau berdua dalam mendidik putranya adalah sebuah pola asuh demokratis dan islami, bukan pola asuh penelantar, permisif maupun otoriter. Pola asuh demokratis ala Nabi Ibrahim As. itulah seperti cermin yang bisa kita jadikan ukuran, contoh dan teladan dalam kehidupan kita.

Istilah empat tipe pola asuh sebagaimana tersebut di atas, awalnya dikembangkan pertama kali oleh Diana Baumrind. Dari hasil risetnya, pola asuh anak yang dimaksud adalah: pola asuh demokratis, otoriter, permisif dan penelantar (Diana Baumrind, 1967: 23-89).

Secara lebih rinci, Diana Baumrind mengurai satu per satu apa yang dimaksud dari semua pola asuh tersebut. Pertama, pola asuh demokratis dimaknai sebagai pola asuh yang dialogis. Caranya ada interaksi dua arah yang seimbang. Anak adalah pusat perhatian dan prioritas. Namun bukan berarti orang tua tidak punya kendali. Di sini, orang tua dan anak saling berhubungan dan saling berusaha mengerti satu sama lain. Diungkapkan, orang tua dengan pola 
asuh ini perlu berperan dan bersikap lebih rasional. Maksudnya, bagaimana orang tua selalu mendasari tindakannya pada rasio atau pemikiran-pemikiran yang terbaik. Dalam hal ini, orang tua juga perlu memberikan kebebasan kepada anak untuk memilah-memilih, melakukan suatu tindakan atau bahkan ikut memberi solusi yang terbaik.

Kedua, pola asuh otoriter diartikan sebagai lawan dari tipe demokratis. Biasanya, orang tua menjadi satu-satunya pengendali yang harus diikuti tanpa kompromi dan dialog. Bahkan, terkadang disertai dengan ancaman-ancaman. Orang tua tipe ini juga cenderung memaksa, memerintah, menghukum. Apabila anak tidak mau melakukan apa yang dikatakan oleh orang tua, maka orang tua tipe ini tidak segan menghukum anak. Orang tua tipe ini biasanya tidak memerlukan umpan balik dari anaknya untuk mengerti mengenai situasi dan kondisi anaknya.

Ketiga, pola asuh permisif diartikan sebagai pola asuh pemanja. Peran orang tua biasanya memberikan pengawasan yang sangat longgar. Memberikan kesempatan pada anaknya untuk melakukan sesuatu tanpa pengawasan yang cukup. Mereka cenderung tidak menegur atau memperingatkan anak apabila anak sedang salah atau melakukan perbuatan seenaknya.

Keempat, tipe penelantar. Orang tua tipe ini biasanya cuek alias kurang memberi perhatian pada anak. Seringkali orang tua kurang memberikan waktu dan perhatian yang cukup untuk anak-anaknya. Waktu mereka banyak digunakan untuk keperluan pribadi mereka sendiri, seperti bekerja, dan juga kadangkala biayapun dihemat-hemat dan kadang hanya digunakan untuk kepentingan orang tuanya sendiri. Naudzubillah!

Dalam konteks inilah, ibadah penyembelihan hewan qurban yang menjadi bagian dari syari'at Islam, yang selalu dilaksanakan setelah shalat ied setiap tahun adalah bentuk penjelmaan dari keshalihan, ketaqwaan dan keikhlasan nabi Ismail kepada Tuhannya. Lebih dari itu, proses sejarahnya sejalan dengan pola asuh demokratis bernuansa Islami sebagaimana ditunjukkan Nabi Ibrahim sebagai orang tua ketika ia bermimpi disuruh oleh Allah., s.w.t, untuk menyembelih putera kesayangannya, Nabi Ismail as. Nabi Ibrahim tidak lantas menyembelih puteranya begitu saja, tetapi ia justru mengajak dialog dan memberi tawaran sekaligus meminta masukan dan bahkan persetujuan anaknya.

Apa dan bagaimana respon anaknya nabi Ibrahim? Ternyata nabi Ismail a.s. sebagai anak Nabi Ibrahim menyambut baik dengan penuh ikhlash menerima tawaran ayahandanya untuk disembelih sebagai pembuktian cintanya kepada Allah., s.wt. Nabi Ismail telah mampu mengalahkan keinginan nafsu dan tuntutan dunianya, karena sadar bahwa cinta dan ridhanya 
kepada Allah melebihi segalanya. Inilah cerita di balik peristiwa keshalehan, ketaqwaan dan keta'atan Ismail diabadikan Allah., s.w.t, dalam al-Qur'an dan sejarah hidupnya menjadi napak tilas pelaksanaan ibadah haji sampai hari ini dan akhir hayat nanti. Subhanallah!

Secara terang-terangn, kisah pola asuh demokratis tersebut diungkap dalam al-Qur'an surat As-Saffat, 37: 102: "Maka ketika anak itu sampai (pada umur) sanggup berusaha bersamanya (Ibrahim) berkata, "Wahai anakku! Sesungguhnya aku bermimpi bahwa aku menyembelihmu. Maka pikirkanlah bagaimana pendapatmu!” dia (Ismail) menjawab, “wahai ayahku" lakukanlah apa yang diperintahkan (Allah) kepadamu. Insya Allah engkau akan mendapatiku termasuk orang yang sabar.”

Dari sini, tidak ada kelirunya bila kita semua dan segenap umat Islam yang menyembelih hewan qurban pada hari raya qurban, mari berusaha berqurban dengan senang dan ikhlas lillahi ta'ala. Artinya berkurban dengan landasan cinta dan taqwa hanya semat-mata karena Allah., s.w.t. Dalam hal ini, tentu kita berusaha menghindarkan diri dari riya' dan motivasi yang bisa merusak pahala qurban yang dilakukan. Pasalnya, kita semua diingatkan Allah., s.w.t, agar senantiasa berkurban dengan penuh ikhlas tanpa batas seperti diurai dalam Q.S. Al-Hajj. 22: 37, yang berbunyi: "Daging-daging unta dan darahnya itu sekali-kali tidak dapat mencapai (keridhaan) Allah, tetapi Ketakwaan dari kamulah yang dapat mencapainya. Demikianlah Allah telah menundukkannya untuk kamu supaya kamu mengagungkan Allah terhadap hidayah-Nya kepada kamu. dan berilah kabar gembira kepada orang-orang yang berbuat baik."

Tidak hanya itu, selain keteladanan keluarga Nabi Ibrahim., a.s, dan sang putera Nabi Ismail dalam hal ketaatannya dan keikhlasannya yang luar biasa dalam menjalankan perintah Allah., s.w.t, dengan menepis berbagai bentuk godaan syaithan, hikmah lain yang bisa dipetik dan diambil pelajaran untuk kita ikuti dalam merayakan setiap hari raya Idul Adha adalah perlunya memupuk semangat untuk memiliki dan membagi.

Pesan implisit ini terbaca dari dari dua ibadah yang dilaksanakan umat Islam mengiringi perayaan Idhul Adha, yakni menyembelih kurban dan melaksanakan haji bagi muslim yang mampu. Setiap muslim yang ingin menyempurnakan kemuslimannya akan berusaha keras untuk melaksanakan kedua ibadah tersebut. Mengingat salah satu kemampuan yang dibutuhkan adalah dari segi finansial, maka dengan sendirinya keinginan kuat itu harus diwujudkan dengan ikhtiar mengumpulkan sejumlah dana yang diperlukan. 
Dari sisi inilah hikmah mesti dipetik umat Islam setiap kali merayakan `Idhul Adha, bahwa sesungguhnya ajaran Islam mendorong umatnya untuk bisa memiliki atau mampu secara finansial agar keislamannya bisa disempurnakan.

Tak hanya berhenti pada semangat memiliki, melainkan juga mesti diikuti semangat untuk mau membagi apa yang dimilikinya. Tanpa semangat itu, seorang muslim belum tentu bisa melaksanakan kurban atau haji. Hal ini terbukti bahwa banyak orang yang sudah mampu, tapi enggan berkurban atau melaksanakan haji. Salah satu penyebabnya adalah tidak adanya kemauan dan semangat untuk membagi. Kurban tidak semata-mata menyembelih kambing atau sapi, tapi juga membagikan dagingnya kepada mereka yang berhak. Demikian juga haji, tanpa semangat membagi tentu akan sayang untuk mengeluarkan biaya perjalanan haji yang jumlahnya tidak sedikit.

Semangat memiliki tidak boleh melahirkan tindakan menghalalkan segala cara yang bisa menimbulkan kekacauan kehidupan bermasyarakat. Oleh karena itu ajaran Islam memberikan rambu-rambu yang mesti ditaati setiap muslim dalam berusaha untuk memiliki, yaitu dengan cara yang halal, baik dan wajar.

Dalam Al Qur'an secara tegas dilarang mencari rizki dengan cara yang tidak halal atau bathil (QS. An-Nisa', 4: 29). Misalnya diperoleh dari hasil berjudi (QS. al-Baqarah, 2: 219) atau mencuri (QS. Al-Maidah, 5: 38), korupsi dan cara-cara buruk lainnya. Demikian juga ada hadits yang menyatakan bahwa antara sesama muslim haram darah, harta dan kehormatannya. Jika mencari rizki dengan berdagang hendaknya secara wajar, tidak curang dalam menakar/ menimbang (QS. Al-Muthaffifin, 83: 1-3), dan mengambil keuntungan secara riba sebagaimana diterangkan Allah SWT dalam QS. Ali 'Imran, 3: 130: “Hai orang-orang yang beriman, janganlah kamu memakan Riba dengan berlipat ganda dan bertakwalah kamu kepada Allah supaya kamu mendapat keberuntungan”.

Selain semangat memiliki, Islam juga menyuruh kita untuk mempunyai semangat membagi. Banyak sekali ayat al-Qur'an maupun hadits yang mendorong setiap muslim untuk mau berbagi (berinfaq, bershodaqoh atau berzakat dan sebagainya).

Sayangnya perintah tersebut lebih sering dilihat dari sudut pandang berbeda. Indikasinya paling tidak bisa kita temui, misalnya, masih banyak orang kaya yang enggan berinfaq, bahkan tidak malu menerima infaq, hibah dan sejenisnya yang mestinya tidak berhak mereka terima, setidaknya ada orang lain yang lebih berhak. 
Islam mengajarkan kita untuk membagi sebagian rizki yang kita terima kepada kerabat, anak yatim dan orang miskin sebagaimana dijelaskan dalam QS. al-Baqarah, 2: 177: “Bukanlah menghadapkan wajahmu ke arah timur dan barat itu suatu kebajikan, akan tetapi Sesungguhnya kebajikan itu ialah beriman kepada Allah, hari Kemudian, malaikat-malaikat, kitab-kitab, nabinabi dan memberikan harta yang dicintainya kepada kerabatnya, anak-anak yatim, orang-orang miskin, musafir (yang memerlukan pertolongan) dan orang-orang yang meminta-minta; dan (memerdekakan) hamba sahaya, mendirikan shalat, dan menunaikan zakat; dan orang-orang yang menepati janjinya apabila ia berjanji, dan orang-orang yang sabar dalam kesempitan, penderitaan dan dalam peperangan. mereka Itulah orang-orang yang benar (imannya); dan mereka Itulah orang-orang yang bertakwa."

Secara khusus, perintah berkurban diungkap dalam al-Qur'an yang bisa kita temukan di berbagai surat/ayat, antara lain dalam surat al-Kautsar, 108: 2; surat al-Hajj, 22: 34-35 dan ayat 36; serta surat ash-Shaffat, 37: 102-107. Selain itu, juga dijelaskan oleh Nabi Muhammad dalam berbagai haditsnya yang bisa ditemukan dalam kitab shahih al-Bukhari, Muslim.

Allah SWT berfirman di dalam surat al-Kautsar, 108: 1-2: ”Sesungguhnya Kami telah memberikan kepadamu ni'mat yang banyak. Maka dirikanlah sholat karena Tuhanmu dan berkurban-lah”. Ayat ini menegaskan kepada kita semua bahwa ibadah kurban merupkan ibadah yang perlu dilakukan selain shalat, utamanya bagi yang mampu.

Dalam hal ini, kurban seringkali dipahami juga sebagai hewan yang disembelih setelah melaksanakan shalat Idul Adha dalam rangka mendekatkan diri kepada Allah karena Dia Yang Maha Suci dan Maha Tinggi sebagaimana diungkap dalam al-Qur'an surat al-An'am, 6: 162: "Katakanlah: sesungguhnya shalatku kurbanku hidup dan matiku adalah untuk Allah Rabb semesta alam tidak ada sekutu bagi-Nya.”

Bagi seorang muslim, inti hikmah di setiap perayaan Idul Adha yang dapat diambil dan bisa diaplikasikan dalam kehidupan saat ini hingga akhir hayat nanti adalah marilah berusaha semaksimalnya dalam bertaqwa dengan memupuk semangat memiliki dan membagi dengan penuh keikhlasan. Semangat untuk berbagi antar sesama dengan ikhlas merupakan kunci dan esensi berkorban yang akan menumbuhkan ketentraman, kedamaian dan solidaritas sosial masyarakat dan lainnya.

Akhirnya, semoga kita semua selalu diberi kemudahan, kebahagiaan, kekuatan, kesuksesan dalam bersyukur, beriman, bertaqwa kepada Allah., s.w.t, sekaligus kita semua 
tergolong menjadi orang yang bersemangat untuk berqurban dengan penuh ikhlas lillahi ta'ala, sepanjang hayat masih di kandung badan.

\section{Penutup}

Ajaran dan ibadah haji dan kurban bisa ditafsirkan selain bersifat transendental dalam hubungan manusia dengan tuhannya, juga bisa ditafsirkan secara sosial dalam kaitan manusia dalam hubungannya dengan sesama. Banyak ayat yang menjelaskan bagaimana kesalehan individual perlu adanya upaya untuk diimbangi dengan kesalehan sosial. Ayat-ayat haji dan kurban menunjukkan kepada kita semua perlunya pemahaman yang lebih praktis dan bermakna serta memiliki sumbangan yang besar terhadap sukses dan bahagianya seseorang dalam kehidupan bermasyarakat, berbangsa dan bernegara. Di sinilah, tafsir ibadah kurban dan haji yang lebih sosial kontekstual juga memiliki dimensi kemanfaatan dan kemaslahatan sosial yang luas. Kunci-kunci pemahaman dan penafsiran yang lebih sosial humanis diharapkan berdampak positif bagi pengalaman dan pengamalan ibadah kepada Allah yang benar-benar bermula dari ketulusan hati dan keikhlasan beramal, sehingga bermanfaat dalam kehidupan manusia di dunia hingga akhiratnya. Penafsiran ini diyakini mendorong praktik keberislaman dalam rangkaian ibadah seseorang dalam hubungannya dengan sesama manusia dan alam sekitarnya.

\section{Daftar Pustaka}

Amsari, Fuad. 1995. Islam Kaafah Tantangan Sosial dan Aplikasinya di Indonesia, Jakarta: Gema Isani Press.

Abdurrahman dkk. 2011. Al-Qur'an dan Isu-isu Kontemporer, Yogyakarta: elSAQ Press.

Al-Qattan, Manna Khalil, 2006. Studi Ilmu-Ilmu Qur'an, terj. Mudzakir AS. Jakarta: PT. Pusataka Litera Antar Nusa.

Baidan, Nashruddin. 2011. Wawasan Baru Ilmu Tafsir, Yogyakarta: Pustaka Pelajar.

Boy, Pradana. 2008. Fikih Jalan Tengah: Dialektika Hukum Islam dan Masalah-masalah Masyarakat Modern. Jakarta: PT Grafindo Media Pratama. 
Mustaqim, Abdul. 2003. Madzahibut Tafsir: Peta Metodologi penafsiran al-Qur'an Periode Klasik Hingga kontemporer. Yogyakarta: Nun Pustaka.

Yayasan Penyelenggara Penterjemah/Pentafsir al-Qur'an. 2004. Al-Qur'an dan Terjemahnya, Jakarta: Departemen Agama.

Gusmian, Islah. 2003. Khazanah Tafsir Indonesia, dari Hermeneutika hingga Ideologi, Jakarta: Teraju.

Hidayat, Komaruddin. 1996. Memahami bahasa Agama: Sebuah kajian Hermeneutik, Jakarta: Paramadina.

Izzan, Ahmad, 2011. Ulumul Qur'an: Telaah Tekstualitas dan Kontekstualitas AlQur'an, Bandung: Tafakkur.

Mustaqim, Abdul dan Syamsudin, Sahiron (ed.), 2011. Epistemologi Tafsir Kontemporer, Yogyakarta: LKiS. , 2002. Studi Al-Qur'an Kontemporer, Yogyakarta: PT Tiara Wacana.

Naim, Ngainun. 2009. Pengantar Studi Islam, Yogyakarta: Teras.

Shihab, M. Quraish. 2002. Tafsir Al Mishbah: Pesan, Kesan dan Keserasian Al Quran. Jakarta: Lentera Hati.

, 1997. Wawasan Al Quran: Tafsir Tematik atas Pelbagai Persoalan Umat. Bandung: Mizan.

Syafrudin, 2009. Paradigma Tafsir Tekstual \& Kontekstual, Yogyakarta: Pustaka Pelajar. Wijaya, Aksin. 2009. Arah Baru Studi Ulum Al-Qur'an. Yogyakarta: Pustaka Pelajar. 